\title{
Kinetic Analysis of in vitro Production of Wild-Type Spodoptera frugiperda Nucleopolyhedrovirus
}

\author{
Andréa Farias de Almeida ${ }^{1}$, Gorete Ribeiro de Macedo ${ }^{1}$, Leslie Chee Loong Chan ${ }^{2}$ and \\ Márcia Regina da Silva Pedrini ${ }^{1 *}$ \\ ${ }^{I}$ Departamento de Engenharia Química; Universidade Federal do Rio Grande do Norte; Natal - RN - Brasil. \\ ${ }^{2}$ Australian Institute for Bioengineering and Nanotechnology; The University of Queensland; St Lucia, QLD 4072 - \\ Australia
}

\begin{abstract}
In this study, the kinetic behavior of Sf9 and Sf21 cells used in the production of a baculovirus biopesticide to control the pest of corn Spodoptera frugiperda was analyzed. Kinetic variables such as maximum specific growth rate, cell productivity, mean rate of infection, as well as the mean rate of occlusion body production were determined during the infection of these cell-lines with the extracellular virus of the S. frugiperda nucleopolyhedrovirus (SfMNPV). The Sf9 cell-line resulted in better viral production results $\left(5.0 \times 10^{8} \mathrm{OB} / \mathrm{mL}\right)$ than the Sf21 cell-line $\left(2.5 \times 10^{8} \mathrm{OB} / \mathrm{mL}\right)$.
\end{abstract}

Key words: Baculovirus, in vitro production, kinetic analysis, SfMNPV

\section{INTRODUCTION}

The fall armyworm, Spodoptera frugiperda (J.E. Smith, 1977) (Lepidoptera: Noctuidae), is the main pest of corn on the entire American continent, being responsible for incalculable crop losses. It is currently controlled by chemical pesticides that generally cause environmental damage and health risks. A large problem with this pest is its development into pesticide-resistant populations (Cruz, 2002). As an alternative, biopesticides have been produced that can be applied to various agricultural crops. For this reason, biocontrol has been the focus of innumerable studies, with Brazil leading the research on the use of baculoviruses as biological control agents.

Baculoviruses are host-specific viral biopesticides that are important agents of biological pest control
(Martignoni, 1984; Moscardi, 1999; Moscardi and Souza, 2002). They comprise the largest group of insect viruses and their use in agroecosystems causes minimal disturbance to beneficial arthropods and minimal ecological damage (Szewczyk et al., 2006). They are protected inside protein crystals (occlusion bodies), which permit the formulation of easily-applied biopesticides that are more economical and safer than chemical insecticides. So far, there have been no field reports of insects developing acquired resistance to these viruses (Moscardi, 1999).

Animal cell culture is important because of the possibility of bioproduct synthesis, which is devoted mainly to human and animal health. Products include viral vaccines, monoclonal antibodies, enzymes, hormones and biopesticides. In particular, insect cells play an important role in

\footnotetext{
*Author for correspondence: marcia.pedrini@eq.ufrn.br
} 
the in vitro production of viral biopesticides (Augusto and Oliveira, 2001).

Processes involving the insect cells differ from those using microorganisms, because the former uses the cells extracted from insect tissue and adapted to in vitro culture (Augusto and Oliveira, 2001). Because of advances in cell culture, the production of baculoviruses in insect cells can be achieved in different growth systems, from monolayer static culture to suspension culture using Erlenmeyer flasks, spinners or bioreactors. Most insect cells can be cultured at $25-30^{\circ} \mathrm{C}$ (Agathos et al., 1990); however, the optimal temperature during cell growth and the infection of Sf9 and Sf 21 cell lines is $28^{\circ} \mathrm{C}$ (King and Possee, 1992).

Suspension cultures favor the study of kinetic variables of cell growth and protein production. The cell density is estimated frequently during the entire culture period, since the estimation of specific growth and production rates depends on this variable (Hiss, 2001). The cells used in this study were isolated from the embryonic tissues of the fall armyworm ( $S$. frugiperda), and are known as Sf9 and Sf21 cell lines. These cells are easily adapted to suspension culture (King and Possee, 1992). The cell line used may compromise in vitro production of the baculovirus, by displaying different permissivity of virus replication (Bilimoria et al, 1992). Therefore, even cells permissive to replication can result in different virus production levels depending on the cell line used.

The production of a baculovirus involves the infection of cells permissive to the virus. The in vitro infection process is initiated with extracellular budded virus (BV), which is obtained from the hemolymph of infected insects or from the supernatant of infected cells. When infected, insect cells produce more $\mathrm{BV}$, as well as the occluded form of the virus, Occlusion Bodies (OB) (King and Possee, 1992). OBs are the biopesticidal form of the virus in the field. In addition, in vitro infection can be initiated with Occlusion Derived Virus (ODV) extracted from OB (Lynn, 1994).

The aim of this work was to study the kinetics of cellular growth and of baculovirus production, by infecting suspension-grown Sf21 and Sf9 cells with Spodoptera frugiperda nucleopolyhedrovirus (SfMNPV, isolate 18).

\section{MATERIALS AND METHODS}

\section{Cells}

The insect cell lines (Sf9 and Sf21) used were kindly provided by Embrapa Genetic Resources and Biotechnology, and were originally sourced from the American Type Culture Collection (ATCC, MD)

\section{Virus}

The virus used was Spodoptera frugiperda nucleopolyhedrovirus (SfMNPV) isolate 18, which was isolated from corn fields and kindly donated by Dr. Fernando Valicente - Embrapa Corn and Sorghum.

\section{Cell culture}

Cells were adapted and cultured in shake flasks (Certomat MO II - B. Braun) at $120 \mathrm{rpm}$ and $28^{\circ} \mathrm{C}$ using HyQ SFX-Insect ${ }^{\mathrm{TM}}$ (HyClone) medium supplemented with $5 \%(\mathrm{v} / \mathrm{v})$ of fetal bovine serum (FBS) (Invitrogen). Cell subcultures were performed every 72 to $96 \mathrm{~h}$ to maintain them in the exponential growth phase. Cell concentration was estimated using a phase contrast microscope (Olympus, Japan) and a Neubauer hemocytometer (Bright-Line Hemocytometer, Sigma). The concentration of viable cells and viability were determined by the trypan blue exclusion technique (Sigma-Aldrich) at a final concentration of $0.1 \%$ $(\mathrm{v} / \mathrm{v})$. A $15 \%$ deviation was obtained by daily counting in triplicate of 200 cells on both sides of the hemocytometer (Nielsen et al., 1991).

\section{In vitro infection with budded virus of SfMNPV}

For kinetic analysis of the baculovirus, both Sf9 and Sf21 cells were infected with the Budded Virus (BV) of SfMNPV. BVs were obtained from a preliminary in vitro infection initiated with Occlusion-Derived Virus (ODV) liberated from caterpillar-produced Occlusion Bodies (OB) (Lynn, 1994). This initial infection was set up (in both Sf9 and Sf21 cells) to obtain the Passage 1 virus stock (containing BV), which was the recovered supernatant after centrifugation $(1000 x g$ for $10 \mathrm{~min}$ ) of the infected cell culture. For Passage 2 virus infections, $3 \mathrm{~mL}$ of Passage 1 virus stock was used to infect $30 \mathrm{~mL}$ shaker cultures of Sf9 and Sf 21 cells (respectively), at an initial cell density of $5 \times 10^{5}$ viable cells $/ \mathrm{mL}$. Noninfected cell culture controls were also set up at 
the same cell density. The cell densities and growth rates were determined daily. At the end of 10 days post infection (dpi), OB production in infected cells was determined by $\mathrm{OB}$ counts using a Neubauer hemocytometer (Bright-Line Hemocytometer, Sigma). All the experiments were done in triplicate.

\section{Kinetic variables}

The maximum cell-specific growth rates of the control and infected cells $\left(\mu_{\mathrm{x}}\right)$ were estimated by Neperian logarithmic linear fitting of cell density with cultivation time during exponential growth. The angular coefficient of this curve was the maximum specific growth itself. The mean infection rate $\left(\mathrm{K}_{\mathrm{d}}\right)$ and mean $\mathrm{OB}$ production rate $\left(K_{\mathrm{P}}\right)$ were calculated by linear fitting of experimental data during the exponential growth phase of infected cells.

\section{RESULTS AND DISCUSSION}

Fig. 1 shows the growth curve of $\mathrm{Sf} 9$ cells in HyQ SFX-Insect ${ }^{\mathrm{TM}}$ (HyClone) medium supplemented with 5\% FBS for both infected and non-infected (control) cells. For the control culture, a maximum cell density $\left(\mathrm{X}_{\max }\right)$ of $7.4 \times 10^{6}$ viable cells $/ \mathrm{mL}$ was recorded after five days of culture and a cell productivity $\left(\mathrm{P}_{\mathrm{x}}\right)$ of $0.77 \times 10^{6}$ cells $/ \mathrm{mL}$.d. was recorded over nine days of culture. The infected culture reached a maximum cell density $\left(\mathrm{Xi}_{\max }\right)$ of $1.0 \times 10^{6}$ viable cells $/ \mathrm{mL}$ at four days post infection (dpi) and a cell productivity $\left(\mathrm{P}_{\mathrm{xi}}\right)$ of $0.068 \times 10^{6}$ cells $/ \mathrm{mL} . \mathrm{d}$.

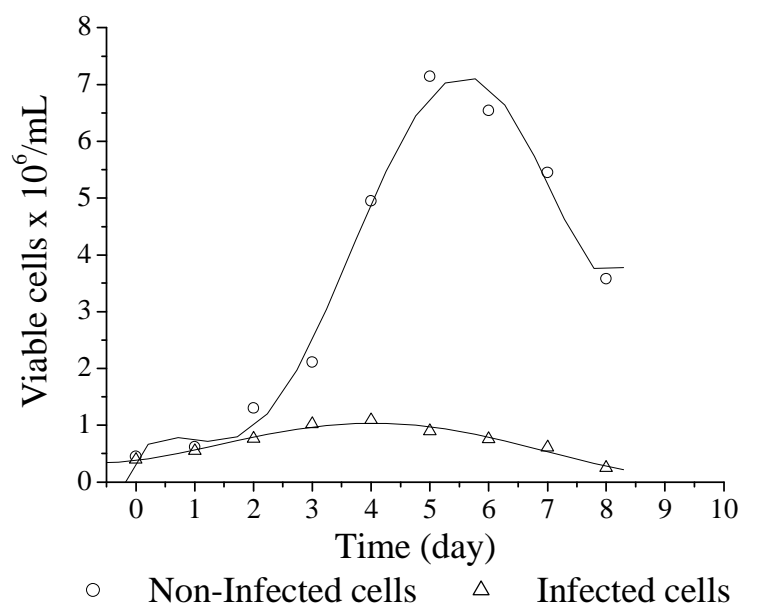

Figure 1 - Growth curve of non-infected and infected Sf9 cells.

The maximum specific growth rates of noninfected $\left(\mu_{x_{\max }}\right)$ and infected cells $\left(\mu_{d}\right)$ Sf9 cells were estimated by logarithmic transformation of the cell growth curve during the exponential growth phase (observed between 1 and 4 days of culture for the non- infected cells and from 0 to 3 days of culture for the infected cells). The estimations were $0.596 \mathrm{~d}^{-1}$ for $\mu_{x_{\max }}$ and $0.321 \mathrm{~d}^{-1}$ for $\mu_{d}$. The mean infection rate $\left(\mathrm{K}_{\mathrm{d}}\right)$ for $\mathrm{Sf} 9$ cells was estimated at 0.196 cells $/ \mathrm{mL}$.d. The production of $\mathrm{OB}$ in $\mathrm{Sf} 9$ cells is depicted in Fig. 2. The maximum $\mathrm{OB}$ production was $5.0 \times 10^{8} \mathrm{OB} / \mathrm{mL}$ at
9 dpi and the mean $\mathrm{OB}$ production rate $\left(\mathrm{K}_{\mathrm{p}}\right)$ was estimated at $11.070 \mathrm{OB} / \mathrm{mL} . \mathrm{d}$.

Fig. 3 shows the growth of non-infected and infected Sf21 cells, under the same culture conditions as those for Sf9 cells. For non-infected cells, the maximum cell density $\left(\mathrm{X}_{\max }\right)$ was $10.0 \mathrm{x}$ $10^{6}$ viable cells $/ \mathrm{mL}$ and the cell productivity $\left(\mathrm{P}_{\mathrm{x}}\right)$ was $1.1 \times 10^{6}$ cells $/ \mathrm{mL} . d$. Infected cells had a maximum cell density $\left(\mathrm{Xi}_{\max }\right)$ of $0.7 \times 10^{6}$ viable cells $/ \mathrm{mL}$ and cell productivity $\left(\mathrm{P}_{\mathrm{xi}}\right)$ of $0.024 \times 10^{6}$ cells/mL.d. 


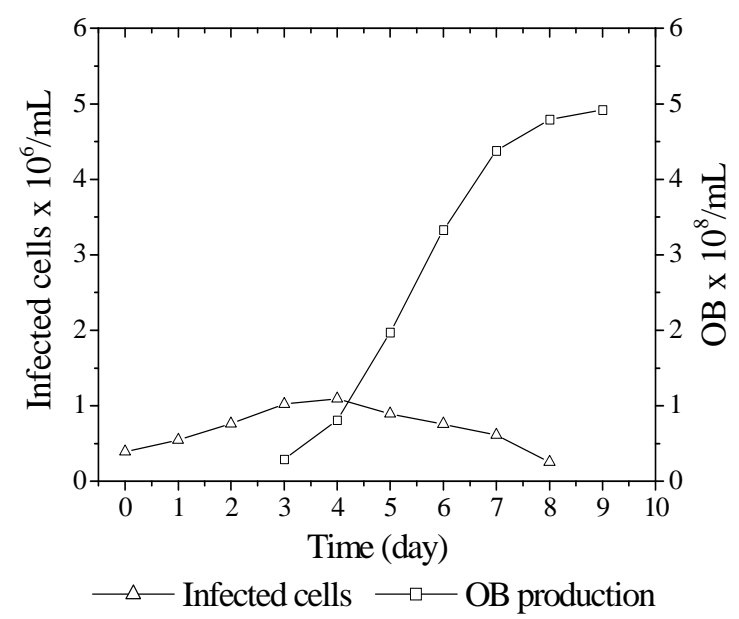

Figure 2 - Growth curve of infected Sf9 cells and OB production curve.

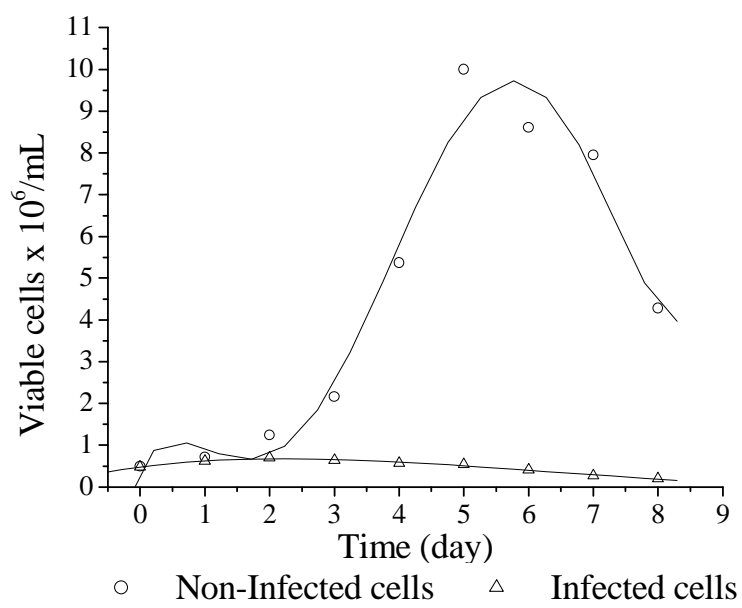

Figure 3 - Growth curve of non-infected and infected Sf21 cells.

The maximum specific growth rates of noninfected $\left(\mu_{x_{\max }}\right)$ and infected $\left(\mu_{d}\right)$ Sf 21 cells were calculated by logarithmic transformation of the cell growth curve during the exponential phase (observed between 2 and 5 days of culture for the non-infected cells, and from 0 to $2 \mathrm{dpi}$ for the infected cells). The estimations were $0.718 \mathrm{~d}^{-1}$ for $\mu_{x_{\max }}$ and $0.191 \mathrm{~d}^{-1}$ for $\mu_{d}$. The mean infection rate $\left(\mathrm{K}_{\mathrm{d}}\right)$ for $\mathrm{Sf} 21$ cells was estimated at 0.087 cells/mL.d .

OB production in Sf21 cells is shown in Fig. 4. The maximum OB production was $2.5 \times 10^{8}$ $\mathrm{OB} / \mathrm{mL}$ at $9 \mathrm{dpi}$, and the mean $\mathrm{OB}$ production rate $\left(\mathrm{K}_{\mathrm{p}}\right)$ was $0.583 \mathrm{OB} / \mathrm{mL} . \mathrm{d}$. 


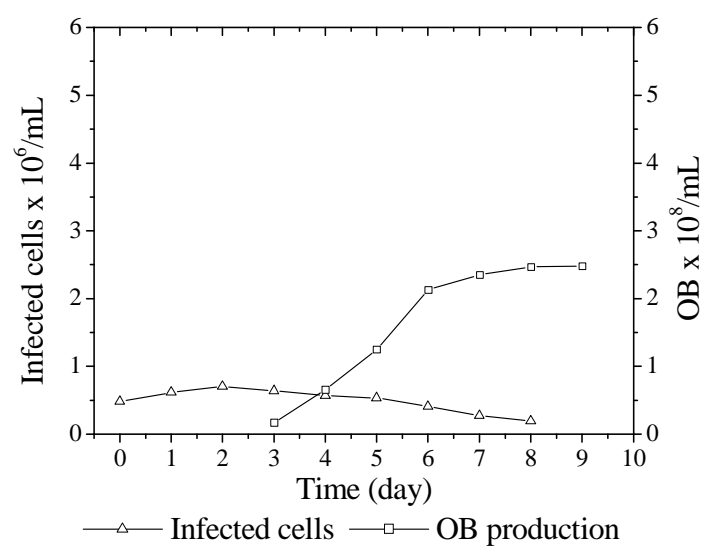

Figure 4 - Growth curve of infected Sf21 cells and OB production curve.

The infection kinetics of Sf9 and Sf21 cells (within 4 and $3 \mathrm{dpi}$, respectively) followed a simple zero-order linear kinetic model. The angular coefficient of the infected cell growth profile, fitted by a linear regression, was the proper velocity constant and defined as the mean infection rate $\left(\mathrm{K}_{\mathrm{d}}\right)$. The rate of OB production $\left(\mathrm{K}_{\mathrm{p}}\right)$ can be defined in a similar way. It would be useful to compare the kinetics of non-infected Sf9 and Sf21 cell growth in suspension cultures (HyQ SFX-Insect ${ }^{\mathrm{TM}}$ (HyClone) medium) obtained from this work with those of other cell culture systems from the literature. Hild et al. (1992) showed that Sf9 cells grown in TC-100 medium supplemented with $5 \%(\mathrm{v} / \mathrm{v})$ FBS reached a maximum density of between 2.9 and $3.8 \times 10^{6}$ cell $/ \mathrm{mL}$ and a specific growth rate of $0.67 \mathrm{~d}^{-1}$. Fernandes et al. (2005) showed that ST (Swine testis) cells grew to a maximum viable cell density of $1.6 \times 10^{6}$ cells $/ \mathrm{mL}$, and exhibited a cell productivity of $0.34 \times 10^{6}$ cells/mL.d. Barral et al. (2005) demonstrated that S2 cells (Drosophila melanogaster) could be grown to a maximum cell density of $4.5 \times 10^{6}$ cells $/ \mathrm{mL}$, with a maximum growth rate $\left(\mu_{\max }\right)$ of $\left.0.68 \mathrm{~d}^{-1}\right)$ and a cell death rate $\left(\mu_{\mathrm{d}}\right)$ of $2.8 \times 10^{3} \mathrm{~d}^{-1}$.

The Sf9 and Sf21 cell lines in this work showed a higher level of cell production than the other cell lines mentioned above. However, the duration of the exponential growth phase and the specific growth rates were quite similar among the cell lines being compared (Table 1).

These findings showed that the values obtained in our study were consistent with literature data.

Table 2 summarizes the kinetic variables obtained from this work for infected Sf9 and Sf21 cells: including the specific infected growth rate, cell productivity, mean infection rate, and mean $\mathrm{OB}$ production rate.

Table 1 - Comparing the growth kinetics of non-infected Sf9 and Sf21 cells with those of other animal cells.

\begin{tabular}{|c|c|c|}
\hline \multirow{2}{*}{ Kinetic Variables } & \multicolumn{2}{|c|}{ Cells } \\
\hline & Sf9 & Sf21 \\
\hline $\mathrm{X}_{\text {initial }}\left(\right.$ cells.mL $\left.\mathrm{mL}^{-1}\right)$ & $0.5 \times 10^{6}$ & $0.5 \times 10^{6}$ \\
\hline $\mathrm{X}_{\text {maximum }}\left(\right.$ cells.mL $\left.\mathrm{mL}^{-1}\right)$ & $7.4 \times 10^{6}$ & $10.0 \times 10^{6}$ \\
\hline$\Delta \mathrm{X}_{\text {maximum }}\left(\right.$ cells. $\left.\mathrm{mL}^{-1}\right)$ & $6.9 \times 10^{6}$ & $9.5 \times 10^{6}$ \\
\hline Duration exp. phase (d) & 3.0 & 3.0 \\
\hline $\mathrm{P}_{\mathrm{X} \max }\left(\right.$ cells.mL $\left.\mathrm{mL}^{-1} \cdot \mathrm{d}^{-1}\right)$ & $0.77 \times 10^{6}$ & $1.1 \times 10^{6}$ \\
\hline$\mu_{X \max }\left(\mathrm{d}^{-1}\right)$ & 0.596 & 0.718 \\
\hline \multirow{2}{*}{ Kinetic Variables } & \multicolumn{2}{|c|}{ Cells } \\
\hline & ST & S2 \\
\hline $\mathrm{X}_{\text {initial }}\left(\right.$ cells.mL $\left.\mathrm{mL}^{-1}\right)$ & $0.21 \times 10^{6}$ & $0.5 \times 10^{6}$ \\
\hline $\mathrm{X}_{\text {maximum }}\left(\right.$ cells.mL $\left.\mathrm{mL}^{-1}\right)$ & $1.6 \times 10^{6}$ & $4.5 \times 10^{6}$ \\
\hline$\Delta \mathrm{X}_{\text {maximum }}\left(\right.$ cells.mL $\left.\mathrm{mL}^{-1}\right)$ & $4.1 \times 10^{6}$ & $4.0 \times 10^{6}$ \\
\hline Duration exp. phase (d) & 3.04 & --- \\
\hline $\mathrm{P}_{\mathrm{Xmax}}\left(\right.$ cells.mL $\left.\mathrm{mL}^{-1} \cdot \mathrm{d}^{-1}\right)$ & $0.34 \times 10^{6}$ & --- \\
\hline$\mu_{\mathrm{Xmax} .}\left(\mathrm{d}^{-1}\right)$ & --- & 0.68 \\
\hline
\end{tabular}


Table 2 - Kinetic results of infections with the SfMNPV virus in Sf9 and Sf21 cells.

\begin{tabular}{lcc}
\hline \multirow{2}{*}{ Kinetic Variables } & \multicolumn{2}{c}{ Cells } \\
\cline { 2 - 3 } & Sf9 & Sf21 \\
\hline $\mathrm{Xi}_{\text {initial }}\left(\right.$ cells. $\left.\mathrm{mL}^{-1}\right)$ & $0.39 \times 10^{6}$ & $0.48 \times 10^{6}$ \\
$\mathrm{Xi}_{\text {maximum }}\left(\right.$ cells. $\left.\mathrm{mL}^{-1}\right)$ & $1.0 \times 10^{6}$ & $0.7 \times 10^{6}$ \\
$\Delta \mathrm{Xi}_{\text {maximum }}\left(\right.$ cells.mL $\left.\mathrm{mL}^{-1}\right)$ & $0.61 \times 10^{6}$ & $0.22 \times 10^{6}$ \\
$\mathrm{P}_{\text {Ximax }}\left(\mathrm{cells} . \mathrm{mL}^{-1} \cdot \mathrm{d}^{-1}\right)$ & $0.068 \times 10^{6}$ & $0.024 \times 10^{6}$ \\
$\mu_{\mathrm{d}}\left(\mathrm{d}^{-1}\right)$ & 0.321 & 0.191 \\
$\mathrm{~K}_{\mathrm{d}}\left(\mathrm{cells} \cdot \mathrm{mL}^{-1} \cdot \mathrm{d}^{-1}\right)$ & 0.196 & 0.087 \\
$\mathrm{~K}_{\mathrm{p}}\left(\mathrm{OB} \cdot \mathrm{mL}^{-1} \cdot \mathrm{d}^{-1}\right)$ & 1.070 & 0.583 \\
\hline
\end{tabular}

The specific growth rate of non-infected Sf 21 cells $\left(\mu_{\mathrm{x} \max }=0.718 \mathrm{~d}^{-1}\right)$ was around $20 \%$ higher than that of non-infected Sf9 cells $\left(\mu_{\mathrm{x} \max }=0.596 \mathrm{~d}^{-1}\right)$. Similarly, the cell productivity of non-infected Sf21 cells was $43 \%$ higher than that of noninfected Sf9 cells $\left(\mathrm{P}_{\mathrm{X} \max }=0.77 \times 10^{6}\right.$ cells $\left./ \mathrm{mL} . \mathrm{d}\right)$, showing that Sf21 cells were totally adapted to the culture conditions developed in this system.

The specific maximum growth rates $\left(\mu_{\max }\right)$ for Sf9 and Sf21 cells were previously reported to be between $0.67-0.83 \mathrm{~d}^{-1}$, which corresponded to a duplication time of around $0.83-1.04 \mathrm{~d}$ (Schaeger et al., 1993). Therefore, the maximum specific growth rates for $\mathrm{Sf} 9$ and $\mathrm{Sf} 21$ cells obtained from this work were in accordance with literature data.

Sf9 cells produced twice as many OBs $\left(5 \times 10^{8}\right.$ $\mathrm{OB} / \mathrm{mL})$ as did Sf21 cells $\left(2.5 \times 10^{8} \mathrm{OB} / \mathrm{mL}\right)$, as shown in Figs. 2 and 4. This could also be demonstrated by the mean rate of product formation, where the rate of OB formation for Sf9 cells $\left(\mathrm{K}_{\mathrm{p}}=1.070 \mathrm{OB} / \mathrm{mL} . \mathrm{d}\right)$ was $83 \%$ higher than that for $\mathrm{Sf} 21$ cells $\left(\mathrm{K}_{\mathrm{p}}=0.583 \mathrm{OB} / \mathrm{mL} . \mathrm{d}\right)$. In addition, Sf9 cells exhibited greater infection efficiency than $\mathrm{Sf} 21$ cells, since the mean infection rate of Sf9 cells $\left(\mathrm{K}_{\mathrm{d}}=0.196\right.$ cells $\left./ \mathrm{mL} . \mathrm{d}\right)$ was 2.25 times higher than that of Sf21 cells $\left(K_{d}=0.087\right.$ cells/mL.d), under the same culture and infection conditions.

\section{CONCLUSION}

This work analyzed the infection kinetics of SfMNPV in both Sf9 and Sf21 cell-lines, which were propagated in suspension cultures $\left(28^{\circ} \mathrm{C}\right.$ and $120 \mathrm{rpm}$ ) using HyQ SFX-Insect ${ }^{\mathrm{TM}}$ (HyClone) medium supplemented with $5 \%(\mathrm{v} / \mathrm{v})$ of FBS. Sf9 cells exhibited a higher mean infection rate $\left(\mathrm{K}_{\mathrm{d}}=\right.$ 0.196 cells $/ \mathrm{mL}$.d $)$ than that of $\mathrm{Sf} 21$ cells $\left(\mathrm{K}_{\mathrm{d}}=\right.$ 0.087 cells $/ \mathrm{mL} . \mathrm{d})$. In addition, Sf9 cells also supported a higher OB yield $\left(5.0 \times 10^{8} \mathrm{OB} / \mathrm{mL}\right)$, with a mean $\mathrm{OB}$ production rate $\left(\mathrm{K}_{\mathrm{p}}\right)$ of 1.070 OB/mL.d.

\section{ACKNOWLEDGEMENTS}

We wish to thank the Conselho Nacional de Desenvolvimento Científico e Tecnológico (CNPq) and the International Foundation Science (IFS) for their financial support.

\section{RESUMO}

Neste trabalho, analisou-se o comportamento cinético das células $\mathrm{Sf} 9$ e $\mathrm{Sf} 21$ utilizadas na produção de biopesticida para o controle de Spodoptera frugiperda. Variáveis cinéticas, como velocidade específica máxima de crescimento, produtividade em células, velocidade média de infecção e a velocidade média de produção de OB foram determinadas durante a infecção destas linhagens com o vírus extracelular do nucleopoliedrovirus de $S$. frugiperda. A linhagem Sf9 resultou em melhores resultados de produção do baculovírus $\left(5 \times 10^{8} \mathrm{OB} / \mathrm{mL}\right)$, quando comparada à linhagem Sf21 $\left(2,5 \times 10^{8} \mathrm{OB} / \mathrm{mL}\right) \mathrm{e}$ outras linhagens da literatura.

\section{REFERENCES}

Agathos, S.N.; Jeong, Y.H. and Venkat, K. (1990) Growth kinetics of free and immobilized insect cell cultures. Annals of the New York. Academy of Sciences 589, 372-398.

Augusto, E.F.P. and Oliveira, M.S. (2001) Processos com células animais. In: Biotecnologia Industrial, Urgel de Almeida Lima et al. (eds.), Editora Edgard Blucher, Brasil, 3, p.547.

Barral, M.F.; Bovo, R.; Soraia, J. A.C.; Gerdulo, M.; Yokomizo, A.Y.; Pereira, C.A. and Augusto, E.F.P. 
(2005) Modelo cinético para crescimento de Drosophila melanogaster (DS-2). Sinaferm.

Bilimoria, S.L.; Demirbag, Z.; Ng, H. and Reinish, A.J. (1992) Abortive cell culture infections of nuclear polyhedrosis viruses as model systems for host specificity. Pesq. Agropec. Bras., Brasilia, 27, p. 123141.

Cruz, I. (2002) Manejo da resistência de insetos-praga a inseticidas, com ênfase em Spodoptera frugiperda (Smith); Sete Lagoas, Embrapa Milho e Sorgo, 15p. Documento 21.

Fernandes, F.T.; Machado, T.; Alli, R.C.P.; Lantieri, V.S.; Gomez, J.G.C.; Freitas, C.M.; Cilento, M. C.; Filho Marchiori, M.; Mozzer, O.D. and Augusto, E.F.P. (2005) Estudo cinético da produção de parvovirus suíno em células ST (Swine testis), Sinaferm.

Hild, H. M.; Emery, A.N. and AL-Rubeat, M. (1992) The effect of $\mathrm{pH}$, temperature, serum concentration and media composition on the growth of insect cells. In: Vlak J.M., Schlaeger E.J. and Bernard, A.R. (eds.). Baculovirus and recombinant protein production processes. p.316-321. Basel: Editiones Roche.

Hiss, H. (2001) Cinética de processos fermentativos. In: Biotecnologia Industrial, Urgel de Almeida Lima et al. (eds.), Editora Edgard Blucher, Brasil, 2, p.93.

King, L.A. and Possee, R.D. (1992) The baculovirus expression system: a laboratory guide London; New York: Chapman and Hall, p.229.

Lynn, D. E. (1994) Enhanced infectivity of occluded virions of Gypsy Moth nuclear polyhedrosis virus for cell cultures. Journal of Invertebrate Pathology, 63, p.268-274.

Martignoni, M.E. (1984) Baculovirus: an attractive biological alternative. In: W. Y. Garner; J. Harvey (Ed.). Chemical and biological controls in forestry. Washington, D.C.: American Chemical Society, p.5567.

Moscardi, F. (1999) Assessment of the application of baculoviruses for control of Lepidoptera. Annual Review of Entomology, 44, p.257-289.

Moscardi, F. and Souza, M. L. (2002) Baculovírus para o controle de pragas: Panacéia ou realidade? Biotecnologia Ciência and Desenvolvimento, 24, p.22-29.

Nielsen, L.K.; Smyth, G.K. and Greenfield, P.F. (1991) "Hemocytometer cell count distributions: implications of non-poisson behavior". Biotechnology Progress, 7, p.560-563.

Schlaeger, E. J; Foggetta M.; Vonach, J.M and Christensen, K. (1993). SF-1, a low cost culture medium for the production of recombinant proteins in baculovirus infected insect cells. Biotechnol. Techn. 7; p. 183-188.

Szewczyk, B.; Hoyos-Carvajal, L.; Paluszek, M.; Skrzecz, I. and Souza, M.L. (2006) Baculoviruses reemerging biopesticides. Biotechnology Advances, 24, p.143-160. 